\author{
ALEKSANDRA RÓŻALSKA \\ EWA SZKUDLAREK-ŚMIECHOWICZ \\ Uniwersytet Łódzki, Wydział Filologiczny, Instytut Filologii Polskiej, \\ Katedra Współczesnego Języka Polskiego
}

\title{
Jak doczekać w dwupaku do dziewiątego miesiąca, czyli językowy obraz ciąży na podstawie forum.e-mama.pl
}

We współczesnym świecie, w którym coraz częściej brakuje czasu na pielęgnowanie kontaktów międzyludzkich, komunikacja za pośrednictwem Internetu staje się doskonałym sposobem na to, aby podtrzymać relacje z drugim człowiekiem lub zawrzeć nowe znajomości. Dyskurs internetowy pozwala zatem zaspokoić naturalną potrzebę komunikacji interpersonalnej.

Celem niniejszej pracy jest zbadanie i analiza językowa jednego $\mathrm{z}$ forum dla kobiet w ciąży, będącego przykładem internetowej komunikacji korespondencyjnej [Grzenia 2006: 43]. Materiał będący podstawą analizy pochodzi z forum internetowego o nazwie: forum.e-mama.pl, które powstało przy portalu Twoja eRodzina. W obrębie forum wyróżnionych jest kilkadziesiąt działów tematycznych, spośród których badaniu poddano tylko działy mające ścisły związek z ciążą i jej przebiegiem, tj.: „Ciąża”, „Ciąża bliźniacza” i „Poród”. Nie brano pod uwagę działów poświęconych zaburzeniom naturalnych procesów fizjologicznych, poronieniom, bezpłodności, a także schorzeniom ginekologicznym, antykoncepcji, opiece i pielęgnacji niemowląt oraz innym aspektom życia codziennego, niezwiązanym bezpośrednio z ciążą.

Słownictwo, jakie zgromadzone zostało do pracy w toku analizy materiału internetowego, skupione jest głównie wokół następujących centrów tematycznych:

1) Nazwy nienarodzonego jeszcze dziecka;

2) Nazwy kobiety w ciąży;

3) Nazwy części ciała kobiety w ciąży i jej dziecka;

4) Nazwy związane z opieką medyczną (m.in. nazwy lekarzy specjalistów, z których pomocy korzystają ciężarne, nazwy badań medycznych, lekarstw i schorzeń typowych dla okresu ciąży);

5) Nazwy związane z najważniejszymi etapami ciąży. 


\section{Nazwy przyszłego dziecka}

Zdecydowanie największa część zgromadzonego słownictwa to określenia przyszłego dziecka. Pojawiają się powszechnie znane i notowane przez słowniki leksemy: syn, córka, brzdąc, maleństwo, skarb, szkrab, najczęściej jednak mamy do czynienia z leksemami należącymi do kategorii zdrobnień i spieszczeń: bąbelek, bobasek, córeczka, córcia, człowieczek, dzidzia, istotka, kruszynka, okruszek, synek, synio, np:

- Jeszcze 2 tygodnie i 4 dni... i mam wykurzyć bąbelka:)

- W przypadku planowania dzidzi to naprawdę szczęście!

- To jest moje maleństwo na USG.

- Zaczynam się cieszyć i będziemy czekać na tą małą istotkę:D

- Czekamy na Ciebie okruszku.

Formanty słowotwórcze pełnią w tych nazwach jednocześnie dwie funkcje: deminutywną i hipokorystyczną [por. Grzegorczykowa 1998: 425, 427]. Przyszłe mamy nie tylko przekazują informację o małym wymiarze desygnatów oznaczanych rzeczownikami, ale przede wszystkim wyrażają swoje pozytywne emocje względem przyszłego dziecka.

Wśród nazw dzieci nie brakuje także wymyślnych form: neologizmów rodzimych (i tworzonych od nich zdrobnień), takich jak: fasolka, fasoleczka, fasolinka, fasolcia (bardzo powszechna w wypowiedziach na forach dla przyszłych matek metafora wskazująca na podobieństwo kształtów: płodu i nasienia fasoli), czy też neologizmów mających obcą podstawę: ang. baby -'małe dziecko, bobas, niemowlę', przyswojoną już jednak do polszczyzny potocznej pod względem fonetycznym i morfologicznym (w tym słowotwórczym): bejbi, bejbuś, bejbusek, bejbik:

- Od którego tygodnia ciąży widać fasolkę na USG dopochwowym?

- Udało się, mam moją fasolinkę.

- Sprawna mama = zdrowy bejbuś = lżejszy poród.

- Stwierdzam, że to dobry czas na drugiego bejbuska.

- Staramy się także z mężem o bejbika, niestety ze względu na moje problemy zdrowotne [...] jestem pod stałą opieką ginekologiczną.

Duże niemowlę określane jest przez użytkowniczki forum nazwą: kolosik, co jest dość szczególnym zabiegiem nominacyjnym, ponieważ znaczenia: podstawy i formantu sufiksalnego są ze sobą sprzeczne. Częste jednak użycie tego leksemu w wypowiedziach przyszłych mam dowodzi, że w tego typu derywatach przeważa funkcja ekspresywna (wyrażania pozytywnych uczuć), natomiast funkcja deminutywna jest funkcją drugorzędną, np.:

- Nie można liczyć na to, że ciuszki będą dopasowane. Może się okazać, że dziecko w nich pływa, albo są nawet za małe, o ile urodzisz kolosika.

- To kolosika będziesz miała.

- Przedstawiam naszego wrześniowego kolosika. 


\section{Nazwy kobiet w ciąży}

Określenia dotyczące ciężarnych są bardzo zróżnicowane pod względem formy. Obok takich leksemów, jak: brzuchatka, ciężarówka (ciężaróweczka), pojawiają się wyrazy mające swe źródło w polszczyźnie handlowo-reklamowej: $w$ dwupaku/dwupak, a także formacje motywowane leksemem fasolka (w znaczeniu: 'płód, nienarodzone dziecko'): zafasolkowana'.

Nazwy kobiet w ciąży tworzone są również od nazw miesięcy, na które przewidywany jest termin porodu: marcóweczka, czerwcóweczka, wrześnióweczka itd:

- No to chyba czas na nas czerwcóweczki 2012:),

- Wszystkiego dobrego i dużo zdrówka stycznióweczki;),

- W zeszłym roku też założyłam wrześnióweczki;).

W tak tworzonych nazwach upatrywać można gwarowego zwyczaju nazywania zwierząt hodowlanych od nazw dni, w których się urodziły (por. nazwy krów: piędzocha, wtorocha, środocha, czwartocha, piątocha, sobocha, niedziocha [Gaertner 1934: 331]). Niewątpliwie jednak użytkowniczki forów nie mają świadomości gwarowego zwyczaju nominacyjnego. Hipokorystyczny przyrostek -óweczka zaciera ponadto pejoratywny wydźwięk takiego skojarzenia.

Ciężarne, które mają zalecenia lekarskie dotyczące leżenia, to leżakujące lub leżace ciężarówki. Dowcip językowy zawarty w tych konstrukcjach ma niewątpliwie terapeutyczną funkcję [por. Kamińska-Szmaj 2001: 132], pomaga bowiem rozładować emocjonalne napięcie towarzyszące zagrożonej ciąży, np.:

- ...ciężarówki leżące z Krakowa...,

- Jak będziesz u rodziców, to będziesz tylko leniuchować i leżakować, więc nic Ci nie grozi.

Kobiety, które cierpią na cukrzycę lub choroby tarczycy, również wyróżniają się spośród „zwyczajnych forumowiczek”, nazywając siebie słodkimi mamusiami, cukiereczkami, tarczycóweczkami, tarczycowymi mamusiami:

- Nikomu nie życzę cukrzycy, ale jeśli są na forum jeszcze jakieś cukiereczki, to proszę - napiszcie, jak sobie radzicie.

- Dobrze, że nas tarczycowych więcej. Nie masz pojęcia, jak podnosi mnie na duchu świadomość, że nie jestem sama.

- Pozdrawiam wszystkie tarczycowe mamuśki.

Określenie: słodkie mamy ma swoje źródło w specjalnym programie o tej samej nazwie, który stworzyła firma Bayer z myślą o kobietach borykających się

${ }^{1}$ Leksem fasolka (w znaczeniu: 'płód, nienarodzone dziecko') tworzy dość liczną rodzinę wyrazów, m.in. fasolkowy, zafasolkować się - 'zajść w ciążęe', zafasolkowana - 'będąca w ciąży', zafasolkowanie - 'zajście w ciążę'. 
z cukrzycą ciążową. Na stronie internetowej programu, którego celem jest edukacja kobiet w ciąży, przekonuje się przyszłe matki o konieczności kontrolowania swojego stanu zdrowia. Informacyjno-perswazyjną funkcję pełni m.in. rymowanka - hasło programu, utrzymane w podobnej do wpisów na forum dość infantylnej stylistyce: „Każda słodka mama mierzy cukier od rana, zdrowo się odżywia, na wadze przybywa, wtedy dzidziuś rośnie i kopie radośnie"2.

Swoją odrębną nazwę mają także kobiety cierpiące na nietypowe, jednostkowe schorzenia, np. podwójne to określenie kobiet z podwójną macicą. Kobiety stosujące podczas ciąży zioła nazywają siebie: ziołopijkami, natomiast kobiety, które mają trudności z zajściem w ciąże, określane są jako staraczki - 'starające się o dziecko'.

\section{Ciąża mnoga: nazwy kobiet i dzieci}

Osobny dział forum dotyczy kobiet w ciąży mnogiej - bliźniaczych (podwójnych) i trojaczych mam. Bliźnięta bywają nazywane podwójnym zestawem albo mniej przedmiotowo - podwójnym szczęściem:

- Mam bliźniaczych jest niewiele dlatego piszemy wszystkie na jednym wątku [...]

- Ja to się tego właśnie boję, że jakby coś znowu się wykluto, to może to być też podwójny zestaw.

- Gratuluję podwójnego szczęścia!

Takie uprzedmiotowienie (por. także m.in.: $w$ dwupaku, ciężarówka - 'kobieta w ciąży', rozpakowana - 'kobieta po porodzie', rozsypać się - 'urodzić') jest, jak należy przypuszczać, przejawem działania tabu językowego, u którego podstaw leży wiara w magiczną moc słowa i magiczne myślenie, którego podstawową cechą jest utożsamianie wyrazu z jego desygnatem [por. Dąbrowska 1992: 124]. Ciąża jest niewątpliwie takim okresem w życiu kobiety, z którym łączy się nie tylko wiele obaw, strach o zdrowie i życie przyszłego dziecka, ale i wiele zabobonów (por. niemówienie bliskim i znajomym o ciąży w pierwszym trymestrze, „żeby nie zapeszyć”; zakaz noszenia przez kobiety w ciąży łańcuszków na szyi, „,bo dziecko udusi się pępowiną” itp.), które z tego strachu i niewiedzy wynikają.

\section{Nazwy części ciała kobiety w ciąży i jej dziecka}

Tak jak nazwy przyszłego dziecka to głównie zdrobnienia i spieszczenia, tak i zdrabnianiu i spieszczaniu podlegają nazwy poszczególnych części ciała (ciałka) przyszłych dzieci: główka, nóżka, płucko, rączka, serduszko, włosek, np.:

${ }^{2}$ http://www.slodkiemamy.edu.pl/ 
- Pamiętam wszystko: całe ciałko w mazi płodowej, jej wyraz twarzy, to jak się poruszała, a reszta... mało ważna.

- A ja jestem w 15 tygodniu i mi gin powiedziała, że ma dużą główkę³.

- Wtedy już będę prawie w 10 tygodniu, więc już chyba będzie widać rączki i nóżki.

- Serduszko się nie pojawiało, straszyli mnie zabiegiem łyżeczkowania.

Ciało kobiety zdaje się sprowadzać tylko do jednej jego części: brzucha, określanego następującymi leksemami: brzuszek, brzuchol, brzunio, brzusio, czy też bardziej metaforycznie: malutkie mieszkanko, które - rzecz jasna - wraz z końcem ciąży zostanie opuszczone:

- Jak rano wstaję brzuszek mam mniejszy (dodam, że jestem w 19 tygodniu ciąży), w porze popołudniowej i wieczornej powiększa się i każdego dnia tak samo.

- Niezły brzunio - mieszkanko ma dzidzia solidne:D.

- Maluszki lubią straszyć, a potem się kiszą w malutkim mieszkanku.

Metafora mieszkanko, właśnie na skutek użycia formy deminutywnej, nasuwa skojarzenia z takimi określeniami, jak: mate, ciasne, ale także przytulne, przyjazne, swojskie, dobrze znane, zapewniające bezpieczeństwo, a więc dzięki użyciu formy zdrobnienia wyraża się jednocześnie pozytywne wartości.

Nazwy innych narządów kobiety nie są zdrabniane, a wręcz przeciwnie zgrubiane, np. serducho, co może służyć podkreśleniu różnicy pomiędzy serduszkiem dziecka a serduchem matki, które musi być na tyle silne, aby zdołało udźwignąć ciężar, jakim dla organizmu matki jest ciąża:

- Na ostatniej wizycie u ginekologa miałam robione KTG serduszka i nic nie było słychać...,

- Chociaż zdarza się, że serducho mi przyspieszy....

\section{Nazwy związane z opieką medyczną}

Ciężarne odbywają liczne wizytki u lekarzy (nie tylko ginekologów), czasem też niezbędna jest wizyta w labu (laboratorium) w celu odebrania wyników jakiegoś badanka, stąd pojawiają się liczne terminy medyczne, które są zdrabniane, co wywołuje groteskowy efekt: hemoroidek, sterydek, krwiaczek, torbielik, witaminka, paciorek (paciorkowiec), rzadziej zgrubienia i neologizmy powstałe w wyniku dezintegracji: pacior (paciorkowiec), oxy (oksytocyna): brzucha.

- Jednego hemoroidka mam na pamiątkę po ciąży, a drugiego od intensywnego ćwiczenia

- Hemoroidka sobie uchowałam.

- Biorę witaminki, ale też niezbyt regularnie.

${ }^{3}$ Pomijam analizę błędnych konstrukcji składniowych, frazeologicznych i innych, których nie brakuje w zgromadzonym materiale. 
- ...[plemniki] powinny się bardziej odbudować po sterydkach.

- Po wizycie za 2 tyg. lekarz stwierdził tylko małego krwiaczka i dalej kazał leżeć.

- ...w każdym razie życzę zwalczenia tegoż paciora.

- Wandzik, ale ty dużo wiesz o tych paciorkach.

- Słyszałam, że po oxy są silniejsze skurcze parte, ale ja nie mam porównania, bo to był mój pierwszy poród.

Nie brakuje także zdrobnień terminów medycznych określających komórki rozrodcze - zarówno żeńskie (jajeczko), jak i męskie (plemniczek, żotnierzyk; zwykle w liczbie mnogiej: plemniczki, żotnierzyki) oraz zdrobnień nazw środków, które kobiety muszą przyjmować dla podtrzymania ciąży: hormonki, luteinka:

- Zanim jednak przyjdą wyniki badań minie trochę czasu, a ja chciałabym dowiedzieć się jak mężczyzna powinien dbać o siebie, aby jego plemniczki były zdrowe i pełne sił;)

- Co innego moje hormonki i temperaturki;)

- Ja też teraz biorę luteinkę od 15 dnia cyklu.

Nad przebiegiem ciąży czuwa ginekolog - zwany ginem, ginkiem lub jeśli mamy do czynienia z kobietą lekarzem - ginka, nierzadko także potrzebna jest kobietom opieka endokrynologa, czyli endo:

- Pielęgniarki w labie i ginka uspokajają mnie, że o cukrzycy nie ma mowy, ale ja swoje wiem i się boję...

- Mnie w pierwszej ciąży ginka zalecała Magnezin.

- Wizytę u gina mam dopiero w przyszłym tygodniu.

- Później recepty może Ci wystawiać gin.

- Byłam 2 dni temu u endo i podniosła mi dawkę Euthyroxu z 50 do 75.

- Teraz czekam na wizytę u endo i wyniki z usg.

Derywacja dezintegralna, charakteryzująca neologizmy typu: gin $(\longleftarrow$ gineko$\log )$, endo ( $\leftarrow$ endokrynolog), labo ( $\leftarrow$ laboratorium), jest powszechna zarówno w odmianach środowiskowych polszczyzny, jak i w nowych środkach przekazu: w Internecie i SMS-ach. Coraz częściej także przenika do polszczyzny potocznej. Wypowiedzi na forach internetowych dla kobiet w ciąży potwierdzają ekspansję tego typu derywacji we współczesnej polszczyźnie nacechowanej emocjonalnie: potocznej i środowiskowej.

\section{Nazwy związane z przebiegiem ciąży}

\section{Starania o dziecko}

Kobiety nie ustają w dążeniach, by zajść w ciążę i w tym celu próbują różnych metod, m.in. kontrolują swój cykl menstruacyjny: mierzą tempkę lub temperaturkę (sufiksacja o funkcji hipokorystycznej), by ustalić moment owulki/owu 
(owulacji) i nazywają siebie - tempkowiczkami. W nazwach typu: owu (dezintegracja), owulka, tempka (w obu derywatach jednocześnie zachodzą dezintegracja i sufiksacja) po raz kolejny widać tendencję do skrótu polegającą na ucinaniu podstaw słowotwórczych. Takie zdezintegrowane podstawy motywują z kolei następne neologizmy (por. tempkowiczka - 'mierząca tempkę $\leftarrow$ temperaturę'):

- Bo jak na razie to znaczący skok masz w 9 dniu cyklu, a to chyba trochę za wcześnie na owu?

- Na stałym poziomie Martynka tempki nie utrzymujesz, bo są te skoki i wahania, przynajmniej na tym wykresie, który ostatnio udostępniłaś.

- Tempki i tempkowiczki, czyli NPR w praktyce:)

- Co innego moje hormonki i temperaturki;)

\section{Poczęcie dziecka}

Sam moment poczęcia dziecka, łączący się ze sferą erotyki, miłością zmysłową, podlega eufemizacji, a przyczyn tabuizacji należy upatrywać we względach wynikających z poczucia przyzwoitości i wstydu [por. Dąbrowska 1992: 138]. Użytkowniczki forów nazywają poczęcie dziecka: złotym strzałem bądź zafasolkowaniem, a akt płciowy: seksikem (hipokorystyczna funkcja przyrostka -ik) lub przytulankami:

- Dziewczyny trzymam kciuki, aby jak najszybciej wszystkie zafasolkowały.

- A więc, w którym dniu cyklu były przytulanki i jaką to zaowocowało płcią?

- Nasze starania to był dosłownie jeden złoty strzał dzień przed owu:)

Najbardziej niepożądanym zjawiskiem fizjologicznym dla starających się o dziecko jest menstruacja, zwana @ (małpą),franca, zolza, zaś ich wymarzonym celem - ujrzenie $d$ wóch kreseczek na teściku (znów pojawiają się formacje deminutywne):

- Dziś zrobiłam teścik i dwie kreski jak byk.

- Mam nadzieję, że za te 3 dni wrzucisz nam zdjęcia pozytywnego teściku:-)

- Czas na nasze dwie kreseczki...

- Moje upragnione dwie kreseczki...

- Gratulacje, oj, jak bym chciała zobaczyć dwie kreseczki u mnie.

Kolejne miesiące (miechy) ciąży (bycia $w$ dwupaku) to czas, kiedy współczesne kobiety, wbrew dość powszechnemu jeszcze przed kilkudziesięciu laty zabobonowi, przygotowują garderobę (ubranka) dla przyszłego potomstwa. Nazwy ubrań to najczęściej derywaty należące do kategorii zdrobnień: śpioszki, pajacyk, kombinezonik, skarpeteczka:

- Co do ubranek to pewnie, że każda kupuje, na co ją stać.

- Skarpeteczki są takie urocze, w ogóle niemowlęce ubranka są takie kochane i malusieńkie.

- ...kaftaniczki maciupkie wiązane na boczku. 


\section{Poród}

Najważniejszym celem e-mam jest doczekać w dwupaku do dziewiątego miesiaca:

- Jestem przekonana, że stycznia w dwupaku nie doczekam.

- Melduję się w dwupaku.

- A Tobie jeszcze trochę zostało czasu w dwupaku.

Poród jest dla ciężarnych zdecydowanie najważniejszym i zarazem owianym największą grozą wydarzeniem, określanym eufemistycznie jako: mistyczny czas przejścia, ewakuacja maluszka z brzuszka czy wyskoczenie maluszka:

- Niestety miałam bóle krzyżowe, pod koniec wiadomo bolało nieziemsko, ale uczucie, kiedy położyli mi córcię na brzuchu - to dopiero wspominam jako mistyczne przeżycie.

- Mały ewakuuje się z brzuszka wtedy, kiedy będzie mu pasowało.

- Tak to jest, że jak trzeba, żeby dzidzia posiedziała w brzuszku, to ona chce na świat, a gdy już może wyskoczyć z brzuszka, to nie chce.

Pojawia się także wiele określeń dźwiękonaśladowczych, być może związanych z wodami płodowymi, jak: chlup, siup czy plum, zastępujących leksem poród:

- Gratuluję! Spokojnych 8 miesięcy i szybkiego chlup!

- Nie pamiętam, co było pierwsze, karmienie dziecka czy wydalenie łożyska (takie krótkie, bezbolesne chlup).

- To chyba znak, że gdzieś tam się oksytocyna juz wytwarza i że do plum blisko?

Sam czasownik urodzić to rozsypać się lub wypakować się, a kobieta po porodzie określana jest jako rozpakowana (lub analogicznie - jeśli wciąż czeka na moment rozwiązania - nierozpakowana):

- Gratuluję wszystkim lutóweczkom!!! Czy wszystkie już wypakowane?

- Ja nadal nierozpakowana, mały ma jeszcze 6 dni.

- Co u rozpakowanych lutówek?

Poronienia są dla niedoszłych mam tematem bardzo trudnym. Mało się o tym mówi (pisze), natomiast tworzone są specjalne działy (niebędące jednak przedmiotem analizy) poświęcone modlitwom za nienarodzone dzieci, czyli Aniołki, którym stawia się specjalne wirtualne znicze: [*]. Czasem kobiety te określają siebie byłymi wrześnióweczkami, czerwcóweczkami - od nazwy miesiąca, na który pierwotnie przewidywane było rozwiązanie ciąży.

W zgromadzonym materiale zdecydowanie dominującym zjawiskiem językowym jest deminutywizacja. Autorki postów zdrabniają nazwy desygnatów należących do realiów otaczającego je świata (stoneczko, spacerek, masażyk, 
necik), części ciała swoich pociech (główka, nóżki, serduszko), pojęcia z zakresu biologii i medycyny (hormonki, luteinka, plemniczki, sterydki, krwiaczek, torbielek), a także nazwy czynności, zjawisk, stanów, m.in.: badanko, wizytka, temperaturka. Może to wynikać z faktu, iż posługując się zdrobnieniami i spieszczeniami łatwiej jest oswoić się kobietom z trudnymi dla nich tematami związanymi z ciążą, porodem czy utratą dziecka. Może to być również naturalny skutek tego, że głównym tematem są dzieci, a więc język także ulega zdziecinnieniu, swego rodzaju infantylizacji.

Drugim co do częstotliwości występowania zabiegiem słowotwórczym jest dezintegracja - skrócenie form językowych, które przez to stają się wygodniejsze w pospiesznej internetowej komunikacji (owu, gin, tempka). Rzadziej występują znaki graficzne, które - jak zauważa Jan Grzenia - służą przede wszystkim wyrażeniu trudnych do opisania za pomocą słów emocji [Grzenia 2006: 90]. Z takimi emocjami mają do czynienia kobiety, które starały się bez powodzenia o dziecko. Rozpacz z powodu menstruacji wyrażają znakiem graficznym @. Z kolei współczucie, chęć wsparcia dla tych, które poroniły, sygnalizowane są za pomocą znaku [*]. Nie brakuje także związanych z porodem określeń dźwiękonaśladowczych, zdających się służyć zmniejszeniu napięcia nerwowego i strachu kobiet przed kulminacyjnym momentem ciąży (plum, chlup, siup). We wszystkich tych środkach widzieć należy przejaw działania tabu językowego od wieków związanego z ciążą: „Misterium powstawania nowego życia otoczone jest szacunkiem i jednocześnie wzbudza pewien lęk - nałożone jest na to tabu" [Dąbrowska 1992: 143]. Tabuistyczną funkcję niewątpliwie przypisać należy leksemom, które reifikują albo kobiety, albo przyszłe dzieci: $w$ dwupaku, ciężarówka, leżakująca, rozsypana, fasolka, podwójny zestaw.

Wszystkie zabiegi językowe pełniące rolę eufemizmów czynią więc łatwiejszym wypowiadanie się na forum publicznym w kwestiach intymnych, o których zwykle trudno mówić w szerokim gronie. Komunikacja internetowa pozwala zachować anonimowość, bez wstydu zwierzać się z osobistych problemów i porozmawiać z osobami mającymi podobne rozterki i wątpliwości, a wszelkie zdrobnienia, skróty i znaki graficzne dają złudne wrażenie zachowania intymności.

Infantylizacja widoczna w wypowiedziach użytkowniczek forum staje się powszechna w internetowym dyskursie, ponieważ - jak zauważa Benjamin Barber - ,infantylizm faworyzuje to, co proste, łatwe i szybkie” [Barber 2008: 165]. Metaforyka forum dla ciężarnych jest niezwykle prosta, unika dualizmów i złożoności, wszystko jest jednoznaczne i dookreślone. Stany fizjologiczne są kojarzone z elementami codziennego życia, które nie mają rzeczywistego związku z ciążą.

Za pośrednictwem portali internetowych zawiązują się między kobietami silne więzy. „Forumowiczki” kontaktują się ze sobą i utrzymują także prywatne wirtualne kontakty, jak również spotykają się w świecie rzeczywistym. Słowa, którymi ciężarne wzajemnie się pocieszają i podnoszą na duchu w trudnym dla nich okresie życia, jakim jest ciąża, mają potężną siłę oddziaływania. Kobiety, piszące na forach internetowych, obdarzają siebie nawzajem ogromnym zaufaniem. 
Wierzą, że rady osób o podobnych doświadczeniach pomogą znaleźć idealne rozwiązanie problemów związanych z ciążą, wierzą w terapeutyczną moc słów, odczuwają potrzebę mówienia (pisania) o swojej sytuacji zdrowotnej na forum. Często nie zasięgają opinii lekarzy lub wątpią w pomoc lekarzy, ponieważ ci nie potrafili udzielić im wyczerpujących, satysfakcjonujących je informacji. Dowodzą tego liczne wypowiedzi użytkowniczek forum, które wielokrotnie podkreślają swoją nieufność wobec opieki medycznej i przyznają, iż niekiedy nie stosują się do zaleceń lekarzy, których porady wzajemnie się wykluczają:

- Martwię się, że gin ostatnio nie zauważył krwiaka, jak myślicie mogło tak być??

- A pierwsze słyszę o takiej głupocie, żeby nie chcieli przyjąć, bo za wcześnie. Jest wykryta ciąża i trzeba ją utrzymać, no chyba, że się nie chce??? Ja bym jak najszybciej zgłosiła się nawet do szpitala, jeśli ten lekarz nie ma czasu...

- Może przebada cię inny lekarz, może on coś zauważy, czego tamten nie zauważył...

- Pielęgniarki w labie i ginka uspokajają mnie, że o cukrzycy nie ma mowy, ale ja swoje wiem i się boję..

Kontakt internetowy z innymi kobietami, które są w podobnej sytuacji życiowej i zdrowotnej, staje się więc ważniejszy niż konsultacja medyczna z lekarzem. Lektura forum pokazuje również wiarę dużej rzeszy kobiet w niekonwencjonalne metody leczenia schorzeń ginekologicznych lub bezpłodności, np. za pomocą ziół.

Poszukiwanie odpowiedzi na dręczące kobiety pytania za pomocą Internetu jest o wiele łatwiejsze aniżeli zasięgnięcie fachowej opinii lekarza. Teksty pisane na łamach forum, opatrzone licznymi emotikonami, akronimami oraz pomysłowe zdrobnienia i skróty w wypowiedziach zapisanych - często $\mathrm{z}$ wieloma błędami - to komunikaty kogoś, kto się spieszy i komu zależy na szybkiej i prostej, a nie przemyślanej odpowiedzi. Istotę forum stanowi wzajemne wsparcie i potrzeba dodania sobie otuchy w trudnych chwilach. Wspólnota dyskursywna „e-mam” opiera się nie tylko na podobnych doświadczeniach, problemach, obawach, ale i wspólnym kodzie przekazu. Jeśli udział w takiej komunikacji jest tylko uzupełnieniem komunikacji ze specjalistą, może zaspokajać ważne potrzeby psychiczne uczestniczek forów. Jeśli ją zastępuje, a niekiedy można odnieść wrażenie, że poszukiwanie porad medycznych stanowi impuls do czynnego udziału komunikacyjnego w forach internetowych, może być niebezpieczny dla zdrowia i życia mam i ich dzieci i świadczyć albo o braku elementarnej wiedzy, albo o braku elementarnego zaufania do środowiska lekarzy.

\section{Bibliografia}

Barber B. R. [2008], Infantylizacja konsumentów: pojawienie się dzieci-dorostych, [w:] tenże, Skonsumowani: Jak rynek psuje dzieci, infantylizuje dorostych i polyka obywateli, Muza S.A., Warszawa.

Dąbrowska A. [1992], Eufemizmy mowy potocznej, [w:] J. Anusiewicz, F. Nieckula (red.), Język a kultura, t. 5: Potoczność w języku i kulturze, Wiedza o Kulturze, Wrocław. 
Gaertner H. [1934], Gramatyka wspótczesnego języka polskiego, cz. III: Słowotwórstwo, Książnica-Atlas S.A. Zjednoczone Zakłady Kartograficzne i Wydawnicze TNSW; (Zakłady Graficzne Ski Akc. Książnica-Atlas), Lwów-Warszawa.

Grzegorczykowa R., Laskowski R., Wróbel H. (red.) [1998], Gramatyka współczesnego języka polskiego. Morfologia, wyd. II zmienione, Wydawnictwo Naukowe PWN, Warszawa.

Grzenia J. [2006], Sytuacje komunikacyjne w Internecie, [w:] Komunikacja językowa w Internecie, Wydawnictwo Naukowe PWN, Warszawa.

Kamińska-Szmaj I. [2001], Słowa na wolności. Język polityki po 1989 roku, Wydawnictwo Europa, Wrocław. 